treatment criteria were in agreement (see table II). This observation was true for measurement both by the physician and by the monitor. If the disagreement was due to a technical error we would expect the measurement error to be greatest in this group of patients. In fact, the measurement error in each group was related to the absolute blood pressure level, as expected from figure 1 . Another explanation could be an inappropriate choice of the treatment threshold. The arbitrary criterion based on reference values obtained in normotensive subjects, however, and the optimal threshold as determined by the receiver operating characteristic curve had comparable decisional value. The sensitivity and specificity of the former method were $61.4 \%$ and $78.1 \%$ respectively, figures not significantly different from those obtained by using the curve $(70.5 \%$ and $81.8 \%$ respectively). Consequently, it is unlikely that the classification obtained here would be altered by the use of a normality criterion derived from a larger sample of normotensive subjects. Classification errors reflect the random variation of blood pressures around the decisional threshold rather than an inappropriate choice of threshold or technical error in measurement.

We conclude that in a population of patients with mild hypertension a single 12 hour ambulatory blood pressure record selects the same proportion of patients to be treated as the WHO-ISH criteria.

Divergent conclusions, however, are often drawn at the individual level, which means that a single 12 hour ambulatory monitoring record cannot be proposed as a substitute for the WHO-ISH recommendations. The simultaneous use of the two methods in the same patient would result in confusion for both patients and physicians, as well as increased health care costs. In the absence of a prospective study comparing the incidence of cardiovascular complications in two groups of patients randomly allocated to one method or the other, a rational choice between these two methods for this type of patient is not possible. This problem is currently being researched by the home versus office monitoring (HOME) study.2 In the meantime the WHO-ISH recommendations remain a reasonable option which takes into account the results of major large scale multicentre controlled trials.

\title{
Risk stratification for open heart surgery: trial of the Parsonnet system in a British hospital
}

\section{Wythenshawe Hospital, Manchester M23 9LT Samer A M Nashef, senior registrar in cardiothoracic surgery Frances Carey, medical audit officer \\ Maureen M Silcock, medical audit coordinator P K Oommen, senior house officer in cardiothoracic surgery Richard D Levy, senior registrar in cardiology M T Jones, consultant cardiothoracic surgeon}

\section{Correspondence to:} Mr S A M Nashef, Papworth Hospital, Papworth Everard, Cambridge CB3 8RE.
We thank Pierre Corvol for his constant support throughout the study and Martin Day for editorial assistance. This work was supported by a grant from the Caisse Nationale d'Assurance Maladie des Travailleurs Salariès. 1. Mancia G, Parati G. Clinical significance of "white coat" hypertension.
Hypertchsiem 1990;16:624-6.

Management Committee of the Australian Therapeutic Trial on Mild Hypertension. Untreated mild hypertension. Lanct 1982;1:185-91.

3 Medical Research Council Working Party. MRC trial of treatment of mild hypertension: principal results. BMf 1985;291:97-104.

+ WHO/ISH. 1989 Guidelines for the treatment of mild hypertension. J Hypertens 1989;7:689-93

5 Pagny JY, Delva R, Aouizerate M, Chatellier G, Battaglia C, Devries C, et al. La pression arterielle ambulatoire des sujets normotendus. Presse Méd 1987:33:1621-4

6 Pagny J-Y, Chatellier G, Devriès C, Janod JP, Corvol P, Ménard J. Evaluation of the Spacelabs ambulatory blood pressure recorder: comparison with the Remler M2000. Cardiovascular Rev Rep 1987;7:31-6.

7 Bland JM, Altman DG. Statistical methods for assessing agreement between two methods of measurement. Lancet 1986;i:307-10.

8 Fleiss JL. Statistical methods for rates and proportions. New York: John Wiley, 1981.

9 Metz CE. Basic principles of ROC analysis. Siminars in Nuclear Medicine 1978:8:283-98.

10 Smith TDW, Clayton D. Individual variation between general practitioners in labelling of hypertension. BMI 1990;300:74-5.

11 Pickering TG, James GD, Boddie C, Harshfield GA, Blank S, Laragh JH How common is white coat hypertension? YAMA 1988;114:925-8.

12 Weber MA, Drayer JIM. Role of blood pressure monitoring in the diagnosis of hypertension. F Hypirtens 1987; 4(suppl 5):S325-S327.

13 Wacher B, Jacot Des Combes B. Porchet M. Biollaz J, Schaller MD. Brunner HR. Ambulatory blood pressure recording to identify patients who truly need therapy. 7 C/hron Dis 1984;37:55-8.

14 Watson RDS, Lumb R, Young MA, Stallard TJ, Davies P, Littler WA. Variation in cuff blood pressure in untreated outpatients with mild hypertension--implications for initiating antihypertensive treatment. hypertension--implications
fHypertells 1987;5:207-11.

15 Conway J, Coats A. Value of ambulatory blood pressure monitoring in clinical pharmacology. F Hypirtens 1989;7(suppl 3):S29-S32

16 Casadei R, Parati G, Pomidossi G, Gropelli A, Trazzi S, Di Rienzo R, et al. 24-Hour blood pressure monitoring: evaluation of Spacelabs 5300 monitor by comparison with intraarterial blood pressure recording in ambulan patients. F Hypertens 1988:6:797-803

17 Burke MJ, Towers HM, O'Malley K, Fitzgerald DJ, O'Brien ET Sphygmomanometers in hospital and family practice: problems and recommendations. BMI 1982;285:469-71.

18 Bruce NG, Shaper AG, Walker M, Wannamethee G. Observer bias in blood pressure studies. F Hypertens 1988;6:375-80.

19 Armitage P, Fox W, Rose A, Tinker CM. The variability of measurements of casual blond pressure. II. Survey experience. Clin Sci 1966;30:337-44.

20 Pickering TG, Harshficld GA, Kleinert HD, Blank S, Laragh JH. Blood pressure during normal daily activities, slecp, and exercise. fAMA pressure during
1985:247:992-6.

21 Staessen Ja, Fagard RH, Lijnen IJJ, Thiis I, Van Hoof R, Amery AK. Mean and range of ambulatory blond pressure in normotensive subjects from meta-analysis of 23 studies. Am f Cardiol 1991;67:723-7.

22 Clement DL. Home versus office monitoring of blood pressure: a European multicentre study of high blood pressure. J Hypertens 1989;7(suppl 3) S49-S51.

(Accepted 28.August 1992)

\section{Patients, methods, and results}

All patients undergoing open heart surgery in the year from 1 March 1991 were studied. Risk data were obtained from the case notes by audit staff, who are not medically qualified. One of us (SAMN) was available to help locate or interpret data in case of difficulty. Predicted mortality was calculated and recorded preoperatively for every patient. Patients were classified into five risk groups: good (predicted mortality $0-4 \%$ ), fair $(5-9 \%)$, poor $(10-14 \%)$, high $(15-19 \%)$, and extremely high risk ( $20 \%$ or more). Operative mortality was defined as death temporally or causally related to surgery (death within 30 days of operation or in the same hospital admission as operation, regardless of cause). Information was entered into a database and results analysed by $\chi^{2}$ test for trend.

There was little difficulty in data collection. Audit staff spent an average of 10 minutes per patient in obtaining information from the case notes and less than five minutes per patient in entering data into the computer. Information was available unambiguously in $92 \%$ of patients and obtained with medical help in the remaining $8 \%$. Of 1071 patients studied, 202 were female $(19 \%)$, 97 were older than $70(9 \%), 317$ were hypertensive $(30 \%), 85$ were diabetic $(8 \%)$, and 17 were morbidly obese $(2 \%)$. Left ventricular function was good in $70 \%$, fair in $26 \%$, and poor in $4 \%$. Only 11 
Predicted versus actual mortality per risk group for all patients and for patients undergoing isolated coronary surgery. (Figures in parentheses are $95 \%$ confidence intervals)

\begin{tabular}{|c|c|c|c|c|c|c|}
\hline \multirow[b]{2}{*}{$\begin{array}{l}\text { Risk } \\
\text { group }\end{array}$} & \multicolumn{3}{|c|}{ All patients } & \multicolumn{3}{|c|}{ Coronary patients } \\
\hline & $\begin{array}{c}\text { No of } \\
\text { deaths/No of } \\
\text { patients }\end{array}$ & $\begin{array}{c}\text { Actual } \\
\text { operative } \\
\text { mortality } \\
(\%)\end{array}$ & $\begin{array}{l}\text { Predicted } \\
\text { operative } \\
\text { mortality } \\
(\%)\end{array}$ & $\begin{array}{c}\text { No of } \\
\text { deaths } / \text { No of } \\
\text { patients }\end{array}$ & $\begin{array}{c}\text { Actual } \\
\text { operative } \\
\text { mortality } \\
(\% / 1)\end{array}$ & $\begin{array}{c}\text { Predicted } \\
\text { operative } \\
\text { mortality } \\
(\%)\end{array}$ \\
\hline Good & $7 / 571$ & $1.2(0.3$ to $2 \cdot 0)$ & $1 \cdot 4$ & $7 / 527$ & $1.3(0.4$ to 2.2$)$ & 1.5 \\
\hline Fair & $10 / 251$ & $4.0(1.6$ to 6.4$)$ & $6 \cdot 3$ & $5 / 137$ & $3.7(0.6$ to 6.8$)$ & $6 \cdot 1$ \\
\hline Poor & $10 / 162$ & $6.2(2.5$ to 9.9$)$ & $11 \cdot 8$ & $4 / 48$ & $8.3(0.5$ to $16 \cdot 1)$ & $11 \cdot 0$ \\
\hline High & $3 / 49$ & $6 \cdot 1(0$ to $12 \cdot 8)$ & $16 \cdot 8$ & $1 / 7$ & $14 \cdot 3(0$ to $39 \cdot 2)$ & $16 \cdot 2$ \\
\hline Extremely high & $6 / 38$ & $15 \cdot 8(4 \cdot 2$ to $27 \cdot 4)$ & $29 \cdot 5$ & $1 / 3$ & $33.3(0$ to 86$)$ & $54 \cdot 0$ \\
\hline Total & $36 / 1071$ & $3 \cdot 3(2.3$ to $4 \cdot 3)$ & $5 \cdot 8$ & $18 / 722$ & $2.5(1.4$ to 3.6$)$ & $3 \cdot 4$ \\
\hline
\end{tabular}

patients $(1 \%)$ were in a catastrophic state. The commonest operation was isolated coronary surgery in 722 patients $(67 \%)$. The two lower risk categories comprised $77 \%$ of patients with $53 \%$ in the "good risk" group.

There were 36 operative deaths $(3 \cdot 4 \%)$. Actual and predicted death rates are detailed in the table. Although actual mortality fell short of predicted mortality in all groups, there was a significant linear relation of increasing mortality by increasing risk $(p<0.001)$. Results were analysed separately for patients undergoing isolated coronary artery surgery (table). Statistical analysis also supported a linear relation $(p<0.001)$.

\section{Comment}

Health expenditure restriction has increased awareness of the cost of treatment. The importance of case mix in cost comparison ${ }^{+}$also applies to quality comparison, which is or should be of equal interest to health purchasers. Quality is notoriously difficult to measure, and interinstitutional comparisons may mislead if not based on sound data. Cardiac surgery is relatively simple to audit among medical specialties: most operations are coronary or valve procedures with predictable results. Although the dictum "cut well, sew well, get well" holds true to a large extent in cardiac surgery, institutions (and surgeons) with higher than average operative mortality may rightly attribute it to having a large proportion of high risk patients in their caseload. Such beliefs cannot be validated unless operative mortality figures are reported in conjunction with risk stratification.
It may be argued that the lowest possible mortality should nevertheless be the aim, thus reflecting both quality of care and judicious case selection. This is fallacious in cardiac surgery because patients who benefit most from operation are often, paradoxically, those at high risk. For example, patients with poor left ventricular function, despite increased surgical mortality, gain more from coronary surgery than lower risk patients with normal left ventricular functions." Similarly, patients with an acute structural defect such as postinfarction septal rupture have a high surgical mortality, but mortality with non-surgical treatment approaches $100 \%$. If these patients are denied surgery most will die, yet operative mortality will be reduced.

Our study shows that the Parsonnet system is applicable to British cardiac surgical practice with little effort and minimal demands on medical time. Some surgeons and cardiologists are dismayed that the system excludes their "favourite" risk factors: unstable angina, lung disease, and severity of coronary lesions are conspicuously absent but are difficult to define (unstable angina), not always documented (lung disease), or both (severity of coronary lesions). It is because such factors are excluded that the Parsonnet system is objective and easy to implement. Our study leads us to recommend it for assessing cardiac surgical results in the United Kingdom.

We are grateful to $\mathrm{Mr} \mathrm{H}$ Moussalli, Mr R A M Lawson, $\mathrm{Mr}$ A K Deiraniya, Mr A N Rahman, and Mr C S Campbell for allowing us to study their patients. We thank Dr E Kyprianou, statistical laboratory, University of Manchester, for his advice and help in statistical analysis. This work was partly supported by a grant from the North Western Regional Health Authority.

1 Dubois RW, Rogers WH, Moxley JH, Draper D, Brook RH. Hospital inpatient mortality: is it a predictor of quality? $N$ Engl M Med 1987;317:1674-80.

2 Dubois RW, Brook RH. Adjusted hospital death rates: a potential screen for quality of medical care. Am F Public Health 1987;77:1162-6.

3 Parsonnet V, Dean D, Bernstein AD. A method of uniform stratification of risk for evaluating the results of surgery in acquired adult heart disease. Circulation 1989;701 (suppl): 13-112

4 Sanderson H. Measuring case mix. BMF 1992;304:1067-8.

5 Alderman EL, Fisher LD, Litwin MS, Kaiser GC, Myers wO, Mavnard C, et al. Results of coronary artery surgery in patients with poor left ventricular function (CASS). Circulation 1983;68:785-95.

(Accepted 16 September 1992)

\section{ONE HUNDRED YEARS AGO}

\section{PUBLIC CONVENIENCES FOR WOMEN.}

The long suffering of women from want of free latrine accommodation in places of public resort, streets of cities, railway stations, etc., seems at length to have attracted such sustained attention in the daily and weekly press and at the meetings of vestries, county councils, railway directors, and others in authority that the grievance seems to be in a fair way of abolition. The Times, by opening its columns to the wail of those who have felt aggrieved by the latest device for the abstraction of the unwilling copper from female suffering humanity, namely, the penny-inthe-slot system, has done excellent service towards the abolition of that special impost, and the whole vicious principle on which it rests; for, why should females pay for an accommodation that is free to men? The London County Council, by recognising the right of each sex to public conveniences free of cost to the users and constructing a plentiful number of the same in the most denselythronged thoroughfares of the metropolis, has conferred a boon on women which is in the highest degree worthy of imitation by other municipal authorities; and now that the Secretary of the London and South-Western Railway has promised, on behalf of his directors, that the objectionable penny-in-the-slot system shall be abolished at the stations of that improving railway, it is much to be desired that other boards of directors will see their way to a prompt decision in the same direction. A calm perusal by each director of the recent public correspondence on the subject, in which the inconvenience of present arrangements - often entailing positive cruelty on unwary females -was well portrayed, would probably lead to a complete abolition, not only of the slot device, but also of the whole system of compulsory payment by women. The withdrawing rooms must of course have caretakers or they would become unfit for use. Let the directors, if they fear the expense of retaining these attendants, permit voluntary contributions from the well-to-do, and there is no reason to fear that the shareholders would then be called upon to bear any of the expense incurred for the attendants' wages. The present arrangement, at any rate, is a very real and pressing grievance, and need only be dispassionately considered to meet with the prompt condemnation of all right thinking men and women.

(BM7 1892;ii;:703) 